This is the peer reviewed version of the following book chapter: Gurnell, A.M. 2016. Trees, wood and river morphodynamics: results from 15 years research on the Tagliamento River, Italy. In Gilvear, D.J., Greenwood, M.T., Thoms, M.C., Wood, P.J. (eds.) River Science: Research and Management for the $21^{\text {st }}$ Century, 132-155, John Wiley and Sons Ltd., Chichester, UK, which has been published in final form at DOI:

10.1002/9781118643525.ch7. This article may be used for non-commercial purposes in accordance with Wiley Terms and Conditions for Self-Archiving.

\title{
TREES, WOOD AND RIVER MORPHODYNAMICS: RESULTS FROM 15 YEARS RESEARCH ON THE TAGLIAMENTO RIVER, ITALY
}

\section{Angela Gurnell}

\section{INTRODUCTION}

\subsection{Trees, wood and river morphodynamics: a context}

The physical character of rivers and their margins depends upon the processes of fluvial sediment transfer from headwaters to mouth and between the main river channel and its river corridor. These transfers influence the morphodynamics of the transitional zone between the low flow channel and the surrounding hillslopes. They result in a wide range of river channel and floodplain styles that have been related to the valley gradient, properties of the river's flow regime, and the calibre and quantity of sediment transported by the river (e.g. Leopold and Wolman, 1957; Schumm, 1977, 1985; Church,1992, 2002; Nanson and Croke, 1992).

Since the early 1980s, researchers have presented increasing evidence that vegetation is also important for river and floodplain morphodynamics. Initially, associations were recognized between the frequency and duration of inundation of a suite of river corridor landforms and the riparian plant communities that grew on them (e.g. Hupp and Osterkamp, 1985). Such associations reflect the fact that many riparian plant species depend on fluvial processes for seed and vegetative propagule dispersal (e.g., Mahoney and Rood, 1998, Merritt and Wohl, 2002, Gurnell et al., 2008, Greet et al., 2011) and for moist, wet or waterlogged soils to support their germination and growth (e.g., Lite et al., 2005, Williams and Cooper, 2005, Pezeshki and Shields, 2006, Gonzalez et al., 2012). They also reflect the fact that riparian species are able to cope with the flow shear stresses, erosion and sedimentation disturbances that are found within river margins.

Riparian plants both affect and respond to fluvial processes. They affect the flow field (e.g., Liu et al., 2010, Bennett et al., 2008) and thus sediment retention and transfer (e.g., Prosser et al., 1995; Ishikawa et al., 2003). Plant roots and rhizomes influence mechanical and hydraulic soil properties (e.g., Docker and Hubble, 2008, Pollen-Bankhead and Simon, 2010), and thus the stability, erosion resistance and soil moisture regime of river margin landforms. Large wood produced by riparian forests, can also protect, reinforce and stabilize landforms (e.g., Abbe and Montgomery, 2003; Gurnell et al., 2005, 2012; Collins et al., 2012).

In recent years, these important interactions and feedbacks between riparian vegetation and fluvial processes and their effect on the character and dynamics of the riparian habitat mosaic, have been explored in several major reviews (e.g. Corenblit et al., 2007, 2009; Gurnell and Petts, 2011; Gurnell, 2012; Gurnell et al., 2012; Osterkamp et al., 2012; Perucca et al., 2012), underpinning the emerging field of fluvial biogeomorphology. 


\subsection{Trees, wood and river morphodynamics: an early conceptual model}

This chapter synthesises research conducted since the late 1990s on the middle and lower reaches of the Tagliamento river (68 to $127 \mathrm{~km}$ from the river's source). The synthesis focuses on interactions between trees, wood and fluvial processes, and their consequences for river morphodynamics, using a conceptual model of island development as a framework for the synthesis (Figure 1, Gurnell et al., 2001).

The conceptual model proposes that three broad categories of tree-related roughness elements contribute to the initiation of island development (seedlings, dead wood, and living (regenerating) wood). These are incorporated in three trajectories of vegetation growth (Figure 1A) on open bar surfaces. Trajectory (a) is initiated by dispersed seed germination across open gravel bar surfaces. Trajectory (b) is initiated by seed germination and regeneration from small pieces of living wood that accumulate with finer sediments in the lee of large (dead) wood accumulations. Trajectory (c) is initiated by regeneration from large living pieces of wood (often entire uprooted trees). All three trajectories involve interaction between the establishing woody vegetation and fluvial processes of erosion and deposition. Trajectory (c) involves the most rapid rates of vegetation growth, retention / aggradation of finer sediment, and development of root-reinforced, erosion resistant, vegetated landforms. Trajectory (a) shows the slowest rates of vegetation growth, sediment retention and landform development.

When these trajectories are set within the context of flood disturbances (Figure 1B), the model proposes that trajectory (a) is very unlikely to lead to the development of islands because the relatively slow growing dispersed seedlings are easily uprooted or buried by fluvial processes before they are able to develop into sizeable plants. Trajectory (c), which supports the most rapid vegetation growth, is most likely to resist flood disturbance and trap sediments to support rapid pioneer island development and coalescence to form building islands and, eventually, established islands (Figure 1A). Trajectory (b) has an intermediate chance of contributing to established island development rather than succumbing to removal of the vegetated patches and landforms by fluvial processes (Figure 1A and B). The relative success of the three trajectories in contributing to island development reflects their different rates of initial above- and below-ground vegetation growth, ability to trap and stabilise finer sediment, and to resist erosion / removal by the sequence of fluvial disturbances to which they are subjected. The same trajectories contribute to the expansion of building and established islands, and also islands dissected from the floodplain by avulsions, leading to the production of complex islands (Figure 1A).

\section{THE TAGLIAMENTO RIVER}

The main stem of the Tagliamento rises close to the Passo della Mauria (1298 m.a.s.1.) in the southern fringe of the European Alps and drains approximately $170 \mathrm{~km}$ to the Adriatic Sea. The climate changes from alpine to mediterranean along the river's course. The river has a flashy flow regime: floods can occur at any time, but are concentrated in spring and autumn as a result of, respectively, snow-melt and thunderstorms.

Apart from its most downstream section, the river is not closely confined by flood embankments. It shows strong downstream changes in valley slope, discharge and bed sediment calibre (Figure 2, Gurnell et al., 2000a, Petts et al., 2000), and is bordered by 
riparian woodland, with distinct downstream changes in dominant tree species (Figure 3, Karrenberg et al., 2003).

Karrenberg et al. (2003) surveyed samples of five $50 \mathrm{~m}^{2}$ vegetated patches located within the active tract and spaced every $10 \mathrm{~km}$ along the main stem. They found a downstream reduction in woody species richness and average patch age (Figure 3A), with distinct variations in the basal area of the woody species along the river (Figure 3B). Alnus incana and Salix eleagnos dominated the headwaters, whereas Populus nigra was found along the middle and lower reaches (Figure 3C).

Populus nigra and several willow species that are present along the Tagliamento (Salix alba, S. daphnoides, S. elaeagnos, S. purpurea, S. triandra) are all members of the Salicaceae family and regenerate freely from deposited uprooted trees and wood fragments, whereas Alnus incana (Betulaceae) regenerates less readily in this way. This partly explains the transition from predominantly dead-wood deposits in the headwater reaches to widespread regeneration from deposited wood in the middle and lower reaches (Gurnell et al., 2000b, Figure 4).

By focusing on reaches between 68 and $127 \mathrm{~km}$ from the river's source, this synthesis refers to reaches dominated by Populus nigra (Figure 3), where a large proportion of wood sprouts following deposition within the active tract (Figure 4), and the river is unconfined by embankments. Section 3 reviews elements of the life cycle of the alluvial Salicaceae (poplars and willows) that are significant for the performance of this family as river ecosystem engineers that influence river morphodynamics, and then presents observations of the growth performance of Populus nigra along the Tagliamento. Section 4 considers the impact of fluvial processes on vegetation dynamics and section 5 presents evidence to support the role of vegetation in influencing river morphology. Finally section 6 considers the impact of changes in fine sediment supply, wood supply and flow regime on the performance of the conceptual model (Figure 1).

\section{GROWTH OF RIPARIAN TREES IN DISTURBED RIPARIAN ENVIRONMENTS}

\subsection{The alluvial Salicaceae}

Riparian zones within the Northern Hemisphere are dominated by species from the Salicaceae (willow and poplar) family, and this is certainly true for the Tagliamento River. Alluvial Salicaceae species are pioneer woody species that have morphological, biomechanical and reproductive characteristics that make them particularly suited to disturbed riparian environments (Karrenberg et al., 2002).

Alluvial Salicaceae species reproduce freely both sexually and vegetatively. In spring, enormous numbers of small, light seeds are produced (Braatne et al., 1996; Imbert and Lefèvre, 2003, Karrenberg and Suter, 2003), which have a very short period of viability. Karrenberg and Suter (2003) observed loss of viability in 75\% seeds retained in dry storage after approximately 30 days for $P$. nigra, 16 to 18 days for $S$. daphnoides and S. eleagnos, and 9 to 12 days for $S$. alba, S. purpurea and $S$. triandra. Loss of viability in the field is likely to be faster. Each species produces seed within a brief time window. In 2000, Karrenberg and Suter (2003) observed a sequence of overlapping seeding periods between mid-April and early-June for $S$. daphnoides, S.purpurea, S. eleagnos, S. triandra, S. alba, and P. nigra at their study site on the middle Tagliamento. Seed production by each species lasted two to three weeks. 
The tiny, light seeds are widely dispersed by wind and water. If they are deposited on moist, bare sediment, they germinate almost immediately, resulting in spatially discrete areas of seedlings that reflect river levels at the time of seed dispersal for each species. Seedlings grow quickly following germination if the alluvial water table does not fall too rapidly and if the young plants are not disturbed by flooding or extreme drought during the first year or two of their development. The ideal soil moisture regime varies between species.

Due to the short period of seed viability, specific germination and early growth requirements, and high sensitivity of seedlings to flood or drought stress, few seedlings grow to maturity. Mahoney and Rood (1998) proposed a 'recruitment box' model that defined the river levels and rates of river level decline required at the time of seed dispersal for successful recruitment of the Salicaceae. Understanding of interrelationships between topographic position, alluvial sediment calibre, and flow regime properties in relation to Salicaceae recruitment has advanced greatly in the last decade (e.g., Amlin and Rood, 2002; Guilloy-Froget et al., 2002; Lytle and Merritt, 2004; Ahna et al., 2007; Merritt et al., 2010), allowing river flow regimes to be designed to promote recruitment of particular species in regulated systems (e.g. Hughes and Rood, 2003; Rood et al., 2005).

The Salicaceae also reproduce asexually. This can occur at any time during the growing season, with regeneration observed from small or large vegetative fragments or entire uprooted trees. From a geomorphological perspective, these fragments can be viewed as 'living wood' (Gurnell et al., 2001), since they can take on the geomorphological role and dynamics of dead wood, but can then gain additional anchorage and above-ground biomass by sprouting roots and shoots. An ability to produce adventitious roots is particularly important in dynamic riparian environments, since this gives these species a high tolerance of burial and resistance to uprooting, and has important implications for alluvial sediment retention, reinforcement and stabilization. Young plants have relatively flexible canopies, allowing them to bend and reduce their flow resistance during floods. Therefore, asexual reproduction is most commonly initiated from established trees, whose canopy is relatively rigid and more susceptible to breakage, and whose substantial internal resources can support the early stages of regeneration in a range of environmental conditions.

In suitable soil moisture conditions, growth rates of seedlings and sprouting rates from vegetative fragments can be extremely high, allowing plants to establish

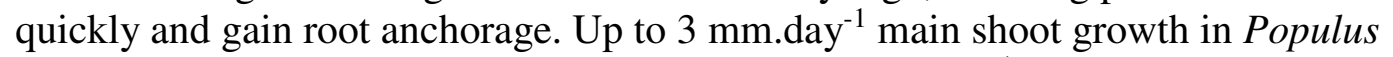

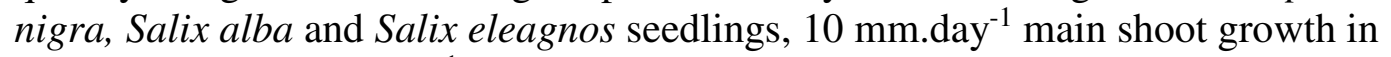
cuttings, and $15 \mathrm{~mm}$. day ${ }^{-1}$ shoot growth from uprooted deposited trees have been observed on the Tagliamento River (Francis et al., 2006, Moggridge and Gurnell, 2009). Root growth is also rapid, with average daily increments in vertical root penetration of sand and gravel substrates of 27 and $20 \mathrm{~mm}$, respectively, for Salix eleagnos, and 15 and $10 \mathrm{~mm}$, respectively, for Populus nigra, observed in experiments where the water table was manipulated to decline at a rate of $3 \mathrm{~cm}^{-d_{a y}}{ }^{-1}$ (Francis et al., 2005).

Laboratory and field experiments on seedlings and cuttings and field observations of established shrubs and trees have also demonstrated that different species of the Salicaceae show varying tolerances to hydrological conditions such as inundation and flood disturbance (Amlin and Rood, 2001; Glenz et al., 2006), and depth to water table and drought (Amlin and Rood, 2002, 2003). This sensitivity to hydrological processes is expressed in the distribution and growth performance of 
different riparian tree species within the riparian zone (e.g. Dixon et al., 2002; Cooper et al., 2006; Turner et al., 2004; Friedman et al., 2006; Robertson, 2006).

\subsection{Riparian tree growth: observations from the Tagliamento River}

Riparian tree growth performance is a key factor in the conceptual model (Figure 1). Many experiments and observations of riparian tree growth performance have been conducted along the Tagliamento, providing information on the growth rate of seedlings, cuttings and deposited trees of different species under varying (temporal and spatial) environmental conditions. In this section, relevant data are presented to characterise variations in growth performance along the middle and lower Tagliamento between 71 and $127 \mathrm{~km}$ from the source, focussing on the dominant riparian tree species in this section of the river: $P$. nigra.

Initial growth of $P$. nigra varies greatly according to propagule type (Figure 5). The Figure provides box plots of the average daily growth achieved during the first growing season at a site $79 \mathrm{~km}$ from the source by the longest shoot of seedlings; $40 \mathrm{~cm}$ long 5-6 mm diameter cuttings; and entire uprooted, deposited trees (average length $=14.2 \mathrm{~m}$, average diameter at $1 \mathrm{~m}$ above the root $\mathrm{wad}=17 \mathrm{~cm}$ ). In all cases the measurements were obtained from bar top locations representing sand to coarse gravel surface sediments, and were collected during 2003 and 2004. Initial growth is stronger from vegetative propagules than from seeds, with uprooted trees showing an order of magnitude larger shoot growth than small cuttings.

Growth rates of P.nigra at the same site after the first growing season are illustrated in Figure 6 . The age of each plant was estimated by counting annual growth segments of the main shoot (younger trees) and annual growth rings at $1 \mathrm{~m}$ above ground level (older trees). There is considerable scatter in annual growth increments between trees of the same age, but there appears to be an increasing average annual growth rate for older trees (up to the maximum 24 years of the sampled trees).

Figures 5 and 6 provide an insight into growth rates from different propagule types and at different growth stages (ages), but they give no indication of growth variability across space and time in response to changing environmental conditions, particularly moisture availability. In order to explore spatio-temporal variations in growth rate, measurements of twenty x $3 \mathrm{~m}$ tall trees $(+/-\mathrm{ca} .40 \mathrm{cms})$ were obtained from fifteen sites along the Tagliamento river between 71 and $127 \mathrm{~km}$ from the source. Small $(3 \mathrm{~m})$ trees were selected to ensure that growth performance reflected recent growing conditions (the previous few years). The sampled trees were located on high bar tops (to control for topographic position) and each tree was isolated from surrounding trees (to control for light receipt and competition for water). twelve of the fifteen sites were sampled in 2005 and fourteen in 2010 (Figure 8). Tree age was determined from growth rings at $1 \mathrm{~m}$ above the ground surface and the average annual growth rate was determined by dividing tree height in excess of $1 \mathrm{~m}$ by the number of growth rings. These measurements revealed a clear downstream pattern in annual growth rates (Figure 7), rising from very low rates at site $1(71 \mathrm{~km})$ to a maximum at sites $6(79 \mathrm{~km})$, where the data for Figures 5 and 6 were obtained) and $7(81 \mathrm{~km})$, then decreasing to site $11(104 \mathrm{~km})$ and increasing again to site $15(127 \mathrm{~km})$. These spatial changes in growth rates of the same tree species correspond to hydrological changes between 71 and $127 \mathrm{~km}$ from the source. Low flow discharges rise between sites 1 (71 $\mathrm{km})$ and $7(81 \mathrm{~km})$ as three tributary streams join the main stem and water is funnelled by the surrounding mountains into a narrow gorge (130 m wide) at $83 \mathrm{~km}$, inducing groundwater upwelling from the alluvial aquifer. Downstream between sites 7 (81 
$\mathrm{km})$ and $11(104 \mathrm{~km})$, there are no significant tributary confluences and the river loses water to a vast alluvial aquifer, leading to a downstream decrease in low flows with the river frequently drying out around site $11(104 \mathrm{~km})$ during the summer. Between sites 11 and 12 (104 to $113 \mathrm{~km}$ ), in association with a regional spring line, low flows increase (Doering et al., 2007) as a band containing silt and clay forces groundwater to the surface (Fontana et al., 2008). The downstream trends in P.nigra growth rates correlate closely with these downstream hydrological changes.

At the 11 sites where measurements were made in 2005 and 2010, the median of the average growth rates observed in 2010 was always greater than in 2005 (Figure 7). Two-way analysis of variance (ANOVA) applied to the observations from these 11 sites explained over $60 \%$ of the variation in growth rates, with significant differences in growth rates between sites $(p<0.001)$, and years $(p<0.001)$ and with a significant interaction between years and sites $(\mathrm{p}<0.001)$, indicating spatial variations in the change in growth rates between 2005 and 2010. A gauge located at $83 \mathrm{~km}$ from the river's source recorded numerous flow pulses in the range 100 to $200 \mathrm{~cm}$ stage in the period between 1 January 2006 and 31 December 2010 (Figure 8 C), whereas flow pulses in this range were relatively rare between 1 January 2001 and 31 December 2005 (not illustrated). A river stage of $200 \mathrm{~cm}$ inundates the braid bars to the level above which large vegetation patches start to appear within the active tract in the reach between 74 and $83 \mathrm{~km}$ from the river's source (Bertoldi et al., 2009; Figure 9), suggesting that ground water levels within the alluvial aquifer were largely within the root zone of these large vegetated patches on frequent occasions between 2006 and 2010. This was not the case between 2001 and 2005, during which river stage remained well below $100 \mathrm{~cm}$ for the majority of the summer growing season in every year (not illustrated). These data support a hydrological cause for the observed differences in average annual growth increment in 2005 and 2010 between river kilometres 74 and 83, since the upper $2 \mathrm{~m}$ growth of the sampled $3 \mathrm{~m}$ trees was largely achieved in the previous 5 years (Figure 7). Since all of the remaining 11 sites are downstream of the gauge at $83 \mathrm{~km}$, they are subject to similar relative water level fluctuations (although related to different local base levels because of spatial variations in surface - groundwater exchange), further supporting a hydrological control on changing growth rates between 2005 and 2010 at all 11 sites.

Tree growth rates are one of the two major controls on island development in the conceptual model (Figure 1), and so these data suggest that spatial and temporal differences in vegetation growth and island dynamics might be expected within different reaches of the Tagliamento main stem.

\section{FLOW DISTURBANCE AND VEGETATION COVER}

Flow disturbance sufficient to erode vegetation and fine sediment is another key factor in the conceptual model (Figure 1). The impact of flood events on vegetation extent is assessed through analysis of satellite imagery, river stage records and photographs, focussing on the section of the river between 68 and $79 \mathrm{~km}$ from the source.

An analysis of the changing percentage of the active tract that is vegetated was conducted using Thematic Mapper ( TM) data for the period 1984 to 2001 (Henshaw et al., 2013). Eighteen TM scenes captured between June and September (when riparian trees have a fully developed leaf cover) during low river flow and cloud-free sky conditions, were analysed. The $30 \mathrm{~m}$ resolution pixels were separated into 
vegetated and unvegetated classes by applying a threshold value of 0.2 to the Normalised Difference Vegetation Index (NDVI, Rouse et al., 1973) and were then accumulated over the area of the active tract to estimate the percentage vegetation cover at each of the eighteen dates. Figure 10A compares the estimates of percentage vegetation cover with the occurrence of river flows exceeding an average $200 \mathrm{~cm}$ stage over one hour (the level above which flows start to interact with large vegetated patches along this section of the river, Figure 9, Bertoldi et al., 2009). Between the August 1984 and September 1994 images, there was only one flow event that clearly exceeded the bankfull level of $300 \mathrm{~cm}$. During this period there was a gradual increase in vegetation cover, with minor reductions following the highest flow levels. Three floods exceeded the $300 \mathrm{~cm}$ level in the period between 1995 and 2001, during which there were no suitable TM scenes for analysis. Indeed, the largest flood in the period from 1982 to 2011 occurred in November 2000, shortly before the September 2001 image. The 2001 image shows a dramatic reduction in vegetation cover in comparison with the 1994 image. Following a bankfull event in 2004, vegetation cover gradually increased in the last five images that were analysed.

Estimates of vegetation cover between 68 and $89 \mathrm{~km}$ were also extracted from higher resolution Aster data (Bertoldi et al., 2011a), allowing a more sensitive spatial analysis of vegetated area. Vegetation cover estimates were based on classification of the $15 \mathrm{~m}$ pixels into heavily vegetated, sparsely vegetated and unvegetated, using threshold NDVI values of 0.2 and 0.1 . Figure 10B presents the total (sparse plus heavy) vegetated area of the active tract, expressed as a percentage, on three occasions (August 2005, July 2008, July 2009). Dense vegetation cover followed a similar downstream pattern on all three dates, but with highest overall cover in 2008 and lowest in 2005. Figure 10B illustrates a rapid expansion in vegetated area between 2005 and 2008, a period during which there were no flow events exceeding $200 \mathrm{~cm}$ river stage by more than $20 \mathrm{~cm}$. However, hourly flood stages of $218 \mathrm{~cm}$ (instantaneous peak stage $>260 \mathrm{~cm}$ ) in August 2008 and $255 \mathrm{~cm}$ in October 2008 resulted in a significant reduction in vegetation cover in the July 2009 image.

In reaches with the highest initial vegetation cover, vegetation expansion was proportionally largest between 2005 and 2008 and vegetation removal was proportionally lowest between 2008 and 2009 (Figure 10B), illustrating that in reaches where vegetation growth is strongest, young vegetation is also most resistant to removal by flooding, presumably because it grows at a very rapid rate. A more detailed temporal picture of changing vegetation cover is provided in Figures $8 \mathrm{~A}$ and B, by including analyses of a further three Aster images (July 2006, September 2009, August 2008 - 14 days after the August flood), and separating the cover estimates into three sub-reaches of contrasting vegetation cover and rate of expansion (68-76 $\mathrm{km}, 78-83 \mathrm{~km}, 83-89 \mathrm{~km})$. Figure 8 verifies the temporal aspect of the conceptual model (Figure 1B) by illustrating how the relatively modest vegetation expansion in the upstream $(68-76 \mathrm{~km})$ and downstream $(83-89 \mathrm{~km})$ sub-reaches between 2005 and 2008 was reflected in a steady increase in the number of vegetated patches, whilst the rapid vegetation expansion in the central subreach $(78-83 \mathrm{~km})$ was accompanied by an initial increase in the number of patches but then some coalescence between 2007 and 2008. Moreover, whereas the two high river stages in 2008 led to a reduction in vegetated area and number of vegetated patches almost back to 2005 levels in the upstream and downstream sub-reaches, only a relatively minor reduction in area and number of patches occurred in the middle sub-reach. Thus, where growth of the dominant riparian tree species, $P$. nigra, is most vigorous (between 78 and $83 \mathrm{~km}$, Figure 7), vegetation cover in the newly vegetated area is sufficiently developed to 
resist erosion by the two flood events, whereas this is not the case in the other two sub-reaches, where $P$. nigra growth rates are significantly slower $(68-76 \mathrm{~km}, 83-89$ $\mathrm{km}$, Figure 7).

Photographs of a section of the river between 80 and $81 \mathrm{~km}$ at times relevant to the changes illustrated in Figures 8 and 10 are presented in Figure 11. In September 2001 the vegetation cover was low almost a year after the very large flood in November 2000. Trees deposited by the flood on the bar top between the two islands in the top right of the photograph and on the bar top towards the left centre of the photograph had sprouted to form pioneer islands, but elsewhere in the active tract, vegetation cover was negligible. By July 2005, the areas between the pioneer islands had become vegetated as the islands coalesced, and there were some new pioneer islands on the bar at the top of the photograph that had developed from trees deposited in a bankfull flood in October 2004. However, other areas remained bare of vegetation, probably as a result of erosion by the same flood. By 2008, the vegetated areas in the 2005 photograph had coalesced to formed established islands and newly vegetated areas had developed across much of the remainder of the bar surfaces. In the 2010 photograph, the established islands present in 2008 remained, but approximately a half of the newly vegetated areas of 2005 had been eroded, presumably during the $250-260 \mathrm{~cm}$ stage events that occurred in the intervening period (Figure 10A).

The above evidence illustrates how rapidly the vegetated area can expand during periods with few floods, and also how quickly new vegetated areas can develop a tall vegetation cover forming established islands. It also shows that once the vegetation is established, it is able to resist erosion by all but the largest floods, and that even relatively young, short vegetation cover can survive moderate flood events.

\section{VEGETATION AND FINE SEDIMENT RETENTION}

The final key factor in the conceptual model (Figure 1) is the retention of sand and finer sediment by vegetation to construct root-reinforced island landforms. There is much field evidence for this process, with established island surfaces elevated over $1.5 \mathrm{~m}$ above the surfaces of the highest gravels bar tops within the active tract.

However, a spatially comprehensive analysis is needed to ascertain whether this process has any significant effect on the morphology of the entire active tract. Such an analysis was applied to $1 \mathrm{~km}$ segments of the active tract between river kilometres 68 and 89 (Bertoldi et al., 2011b).

Vegetation height/biomass and braid plane topography were both analysed using airborne Lidar data collected by the UK Natural Environment Research Council in May 2005. The elevation of the ground surface was estimated from the Lidar data to construct a Digital Terrain Model (DTM). Vegetation height was then calculated as the difference between the interpolated ground surface and the Lidar point cloud across a $5 \mathrm{~m}$ grid. A grid cell was deemed bare of vegetation if none of the points lay more than $1 \mathrm{~m}$ above the surface. Vegetation density was estimated as the proportion of points that lay more than $1 \mathrm{~m}$ above the ground surface in a grid cell. In the same way, the density of vegetation greater than 5,10 and $20 \mathrm{~m}$ tall was estimated as the proportion of points that were higher than these elevations above the ground surface. Downstream slope was estimated from the moving average of bed elevation estimated for all active tract grid cells within an $800 \mathrm{~m}$ square window. In this way, the 
downstream gradient could be subtracted from the DTM, allowing the frequency distribution of bed elevation to be compared among $1 \mathrm{~km}$ segments of the active tract.

Nineteen $1 \mathrm{~km}$ segments of the river were analysed (segments containing a rock cored island and a bedrock confined gorge were excluded). Figure 12 A and B display frequency distributions of bed elevation within the active tract for the most heavily vegetated (Figure $12 \mathrm{~A}$ ) and least heavily vegetated (Figure $12 \mathrm{~B}$ ) $1 \mathrm{~km}$ segments. Each bar in the frequency distributions is subdivided to show the proportion of the grid cells at that elevation which are unvegetated or support vegetation over $1,5,10$ or $20 \mathrm{~m}$ tall. The shape of the two bed elevation frequency distributions in Figures $12 \mathrm{~A}$ and B are completely different, with the least vegetated segment (Figure $12 \mathrm{~A}$ ) showing a more peaked and negatively skewed frequency distribution, whereas the most heavily vegetated segment shows a wide, symmetrical frequency distribution (Figure $12 \mathrm{~B}$ ).

When the skewness (Figure 12 C) and kurtosis (Figure 12 D) of the bed elevation frequency distributions for all nineteen $1 \mathrm{~km}$ segments are plotted against the average tree canopy height within each segment, it is apparent that the morphology of the active tract changes as the average canopy height changes. Bertoldi et al. (2011b) found statistically significant correlations between the skewness and kurtosis of the bed elevation frequency distribution and several other measures of vegetation cover and height (e.g. proportion of the active tract covered by vegetation taller than $5 \mathrm{~m}$, median elevation of vegetated grid cells, tree growth rate (interpolated from Figure 7)). Thus, the bed elevation frequency distribution becomes more symmetrical and wider as tree growth rate, vegetation cover and height, and the median elevation of vegetated grid cells increases, illustrating a clear topographic signature of vegetation within the entire active tract.

\section{CHANGING THE CONTROLLING FACTORS}

This chapter has explored a range of supporting evidence to validate the conceptual model (Figure 1), at least for the middle and lower reaches of the Tagliamento. In particular, it has presented evidence to support the crucial role of riparian tree growth rate, river flow regime, and the retention of fine sediment by vegetation in influencing island formation and morphology of the active tract. In this section, other evidence is presented to explore the consequences when these controls are changed or removed, and to provide information to generalise the functioning of the model across a wider range of environmental conditions.

\subsection{Fine sediment supply}

The supply of fine sediment increases downstream along the Tagliamento as the bed material also fines (Petts et al., 2000). In the middle reaches, the bed material is typically pebble-cobble size (median particle size of lag deposits $=-6 \mathrm{phi}$, average size of largest particles in lag deposits $=-7.5$ phi; Petts et al., 2000) and there is a good supply of sand and finer size sediment. However, in the headwaters the bed material is much coarser, typically cobble-boulder size (median particle size of lag deposits $=-7$ phi, average size of largest particles in lag deposits $=-8$ phi; Petts et al., 2000) and finer sediment supply is relatively limited. In the lower reaches, the bed material is typically pebble size (median particle size of lag deposits $=-5$ phi, average size of largest particles in lag deposits $=-6.5$ phi; Petts et al., 2000) and there is a 
plentiful supply of sand and finer size sediment. However, other factors change along the active tract.

In the headwaters, dead wood dominates (Figure 4), and woody vegetation develops through predominantly sexual reproduction with seeds germinating in the shelter of boulders and dead wood accumulations. Much coarse sediment is delivered to the river corridor by hillslope (e.g. landslide) processes and islands develop opportunistically, often where coarse bed sediment and wood accumulations are not readily mobilised by the river. Vegetation establishment enhances the stability of sediment patches, but island topography results mainly from flow splitting and bed incision around wood and vegetation rather than by island surface aggradation (Gurnell et al., 2001). This process of island development differs from the aggradation model proposed in Figure 1.

In the lower reaches, pioneer islands develop around accumulations or jams of living wood pieces that are often aligned parallel to the main flow direction and located towards the margins of the active tract. Here, the river adopts a wandering to meandering planform as bank sediments fine and the bed gradient reduces. Pioneer islands trap large quantities of finer sediment and frequently join to form living wood cored scroll bars. The buried wood sprouts rapidly, supported by the moist fine sediment, to form lines of shrubs and trees that aggrade quickly to flood-plain level, inducing erosion of the opposite bank and meander migration (Gurnell et al., 2001).

Over all, plentiful fine sediment and a moist growing environment supports the development of aggrading islands, but these islands have a different morphology in reaches of different planform. Furthermore, fine sediment is not essential to island development where sections of the active tract are sufficiently stable to allow vegetation to develop and establish more slowly.

\subsection{River flow regime}

Some insights into how the island model (Figure 1) might operate in lower energy conditions than are typical of the Tagliamento can be extracted from Figure 11. The model emphasises the importance of asexual reproduction in supporting island development. However, during the period of low flow disturbance from 2005 to 2008, the potential for sexual reproduction to support landform development in lower energy river systems became apparent.

Between the 2005 and 2008 photographs (Figure 11), numerous seeds germinated along the margins of the main low flow braid channels in reaches with the highest tree growth rates (Figure 7). The seedlings grew rapidly and, by 2008, channel margin strips of vegetation had a cover exceeding $80 \%$, and canopy height exceeding $1.5 \mathrm{~m}$. Fine sediment, trapped by the vegetation strips during minor flow pulses, formed levée-like structures up to $45 \mathrm{~cm}$ deep. This process appears to be the first stage of bank construction along the low-flow channel margins. These vegetated strip landforms, like those centred on living and dead wood, can also be viewed as (elongated) pioneer islands, which may develop, coalesce, aggrade and eventually merge with the floodplain, but may also be removed or dissected during disturbance events, as illustrated by the 2010 photograph (Figure 11). This evidence indicates that any of the three trajectories shown in Figure 1 may have importance for river morphodynamics depending on the river energy / flow disturbance regime (Gurnell et al., 2012).

\subsection{Wood supply}


The crucial role of wood in driving island development on the high energy Tagliamento River has been revealed by an analysis of historical air photographs covering the main stem between 67 and 8320 (Zanoni et al., 2008). Although numerous other controlling factors may have changed between the 1940s and the present, widespread removal of riparian trees on the floodplain and adjacent hillslopes could be clearly observed in air photographs dated 1944 and 1946. In the same photographs the active tract was much wider than at present and wood accumulations and islands were virtually absent. Over the following decades, the riparian trees recovered, and wood and islands started to spread across the active tract until the mid 1980s. During the 1980s, attachment of islands to the floodplain resulted in active tract narrowing to the current width coupled with the maintenance of an islandbraided planform. These processes were particularly extensive in the river segments that support the highest rates of riparian tree growth.

\subsection{Conclusions}

Over the last 15 years, a great deal has been learnt about trees, wood and the morphodynamics of the Tagliamento River, some of which has been summarised in this chapter. Although focusing on one river system, this research contributes to the rapidly expanding field of fluvial biogeomorphology, and has benefited from 15 years during which hydrological conditions have varied greatly. As a result, it has been possible to investigate the biogeomorphic consequences of periods of low or high flood disturbance and to consider their relevance to a broad spectrum of humid temperate river types.

In a recent review, Gurnell et al. (2012) linked observations across several river systems to identify a range of vegetation-dominated pioneer landforms that characterise humid temperate rivers of different energy. To progress this research, more biogeomorphological data sets are needed. At the same time, further research on the Tagliamento will characterise the growth performance of other riparian tree species, and their contributions to the fluvial biogeomorphological functioning of this system, particularly in the headwaters, where dead wood, sexual reproduction and other riparian tree species than P.nigra, dominate. This information is of scientific interest and is also crucial to developing sustainable approaches to river management that incorporate the key natural processes that drive river morphodynamics.

\section{Acknowledgements}

Many people have contributed to biogeomorphological research on the Tagliamento River. Research was initiated through a collaboration with Peter Edwards, Geoffrey Petts, Klement Tockner and James Ward. Over the ensuing 15 years, numerous others have contributed with Walter Bertoldi, Robert Francis, Alex Henshaw, and Helen Moggridge being involved for sustained periods. In the early days, the research was supported by two small grants from the UK Natural Environment Research Council (Refs: GR9/03249, NER/B/S/2000/00298). More recently the research on the Tagliamento has been supported by a major grant from the Leverhulme Trust (Ref: F/07 040/AP) and broader research on interactions between vegetation and fluvial geomorphology has been supported by the REFORM (REstoring rivers FOR effective catchment Management) collaborative project funded by the European Union Seventh Framework Programme under grant agreement 282656. Geoff Petts was involved in the Tagliamento research from the beginning and he has maintained an active interest, contributing many good ideas despite his 'limited understanding of green things'. 


\section{REFERENCES}

Abbe, T.B., Montgomery, D.R., 2003. Patterns and processes of wood debris accumulation in the Queets river basin, Washington. Geomorphology 51: 81107.

Ahna, C., Mosera, K.F., Sparks, R.E., White, D.C., 2007. Developing a dynamic model to predict the recruitment and early survival of black willow (Salix nigra) in response to different hydrologic conditions. Ecological Modelling 204: 315325.

Amlin, N.A., Rood, S.B., 2001. Inundation tolerances of riparian willows and cottonwoods. Journal of the American Water Resources Association 37(6): 1709-1720.

Amlin, N.M., Rood, S.B., 2002. Comparative tolerances of riparian willows and cottonwoods to water-table decline. Wetlands 22(2): 338-346.

Amlin, N.M., Rood, S.B., 2003. Drought stress and recovery of riparian cottonwoods due to water table alteration along Willow Creek, Alberta. Trees 17: 351-358.

Bennett, S.J., Wu, W., Alonso, C.V., Wang, S.S.Y., 2008. Modeling fluvial response to in-stream woody vegetation: implications for stream corridor restoration. Earth Surface Processes and Landforms 33: 890-909.

Bertoldi, W., Gurnell, A.M., Surian, N., Tockner, K., Zanoni, L., Ziliani, L., Zolezzi, G., 2009. Understanding reference processes: linkages between river flows, sediment dynamics and vegetated landfroms along the Tagliamento River, Italy. River Research and Applications 25: 501-516.

Bertoldi, W., Drake, N., Gurnell, A.M., 2011a. Interactions between river flows and colonising vegetation on a braided river: exploring spatial and temporal dynamics in riparian vegetation cover using satellite data. Earth Surface Processes and Landforms, doi: 10.1002/esp.2166, available on-line.

Bertoldi, W., Gurnell, A.M., Drake, N., 2011b. The topographic signature of vegetation development along a braided river: results of a combined analysis of airborne lidar, colour air photographs and ground measurements. Water Resources Research, doi:10.1029/2010WR010319, available on-line.

Braatne J.H., Rood S.B., Heilman P.E. 1996. Life history, ecology, and conservation of riparian cottonwoods in North America. In: Biology of Populus and its Implications for Management and Conservation (Eds R.F. Stettler, H.D. Bradshaw, P.E. Heilman \& T.M. Hinckley), pp. 57-86. NRC Research Press, Ottawa.

Church, M., 1992. Channel morphology and typology In: C. Callow and G. Petts (Editors), The rivers handbook: Hydrological and ecological principles. Blackwell, Oxford, pp. 126-143.

Church, M., 2002. Geomorphic thresholds in riverine landscapes. Freshwater Biology 47: 541-557.

Collins, B.D., Montgomery, D.R., Fetherston, K.L., Abbe, T.M. 2012. The floodplain large-wood cycle hypothesis: A mechanism for the physical and biotic structuring of temperate forested alluvial valleys in the North Pacific coastal ecoregion. Geomorphology 139-140: 460-470.

Cooper, D.J., Dickens, J., Hobbs, N.T., Christensen, L., Landrum, L., 2006. Hydrologic, geomorphic and climatic processes controlling willow establishment in a montane ecosystem. Hydrological Processes 20(8): 18451864. 
Corenblit, D., Tabacchi, E., Steiger, J., Gurnell, A.M., 2007. Reciprocal interactions and adjustments between fluvial landforms and vegetation dynamics in river corridors: A review of complementary approaches. Earth-Science Reviews 84(1-2): 56-86.

Corenblit, D., Steiger, J., Gurnell, A.M., Tabacchi, E., Roques, L., 2009. Control of sediment dynamics by vegetation as a key function driving biogeomorphic succession within fluvial corridors. Earth Surface Processes and Landforms 34(13): 1790-1810.

Dixon, M.D., Turner, M.G., Jin, C.F., 2002. Riparian tree seedling distribution on Wisconsin River sandbars: Controls at different spatial scales. Ecological Monographs 72(4): 465-485.

Docker, B.B., Hubble, T.C.T., 2008. Quantifying root-reinforcement of river bank soils by four Australian tree species. Geomorphology 100(3-4): 401-418.

Doering, M., Uehlinger, U., Rotach, A., Schlaepfer, D.R., Tockner, K., 2007. Ecosystem expansion and contraction dynamics along a large Alpine alluvial corridor (Tagliamento River, Northeast Italy). Earth Surface Processes and Landforms 32, 1693-1704.

Francis, R.A., Gurnell, A.M., Petts, G.E., Edwards, P.J. 2005). Survival and growth responses of Populus nigra, Salix elaeagnos and Alnus incana cuttings to varying levels of hydric stress. Forest Ecology and Management 210: 291-301.

Francis, R.A., Gurnell, A.M., 2006. Initial establishment of vegetative fragments within the active zone of a braided gravel-bed river (River Tagliamento, NE Italy). Wetlands 26(3): 641-648.

Friedman, J.M., Auble, G.T., Andrews, E.D., Kittel, G., Madole, R.F., Griffin, E.R., Allred, T.M., 2006. Transverse and longitudinal variation in woody riparian vegetation along a montane river. Western North American Naturalist 66(1): 78-91.

Glenz, C., Schlaepfer, R., Iorgulescu, I., Kienast, F., 2006. Flooding tolerance of Central European tree and shrub species. Forest Ecology and Management 235: $1-13$.

Gonzalez, E., Gonzalez-Sanchis, M., Cabezas, A., Comin, F.A., Muller, E., 2010. Recent Changes in the Riparian Forest of a Large Regulated Mediterranean River: Implications for Management. Environmental Management 45: 669-681.

Gonzalez, E., Gonzalez-Sanchis, M.A., Comin, F.A., Muller, E., 2011. Hydrologic thresholds for riparian forest conservation in a regulated large mediterranean river. River Research and Applications. DOI: 10.1002/rra.1436, available online.

Greet, J.O.E., Angus Webb, J., Cousens, R.D., 2011. The importance of seasonal flow timing for riparian vegetation dynamics: a systematic review using causal criteria analysis. Freshwater Biology, DOI: 10.1111/j.1365-2427.2011.02564.x, available on-line.

Guilloy-Froget, H., Muller, E., Barsoum, N., Hughes, F.M.R., 2002. Dispersal, Germination and Survival of Populus nigra L. (Saliacaceae) in Changing Hydrologic Conditions. Wetlands 22(3): 478-488.

Gurnell, A.M. 2012. Wood in fluvial systems. Treatise on Geomorphology. J. Shroder and E. Wohl. San Diego, CA, Academic Press. 9: in press.

Gurnell, A.M., Petts, G.E., Harris, N.,Ward, J.V., Tockner, K., Edwards, P.J., Kollmann, J. 2000a. Large wood retention in river channels: The case of the Fiume Tagliamento, Italy. Earth Surface Processes and Landforms, 25(3): 255275. 
Gurnell, A.M., Petts, G.E., Hannah, D.M., Smith, B.P.G., Edwards, P.J., Kollmann, J., Ward, J.V., Tockner, K., 2000b. Wood storage within the active zone of a large European gravel-bed river. Geomorphology 34(1-2): 55-72.

Gurnell, A.M., Petts, G.E., Hannah, D.M., Smith, B.P.G., Edwards, P.J., Kollmann, J., Ward, J.V., Tockner, K., 2001. Riparian vegetation and island formation along the gravel-bed Fiume Tagliamento, Italy. Earth Surface Processes and Landforms 26(1): 31-62.

Gurnell, A.M., Tockner, K., Edwards, P.J., Petts, G.E., 2005. Effects of deposited wood on biocomplexity of river corridors. Frontiers in Ecology and Environment 3(7): 377-382.

Gurnell, A.M., Thompson, K., Goodson, J. and Moggridge, H., 2008. Propagule deposition along river margins: linking hydrology and ecology. Journal of Ecology, 96: 553-565.

Gurnell, A.M., Bertoldi, W., Corenbit, D. 2012. Changing river channels: the roles of hydrological processes, plants and pioneer landforms in humid temperate, mixed load, gravel bed rivers. Earth Science Reviews 111: 129-141.

Gurnell, A.M., Petts, G.E., 2011. Hydrology and Ecology of River Systems. In: P. Wildere (Editor), Treatise on Water Science. Academic Press, Oxford, pp. 237269.

Henshaw, A.J., Gurnell, A.M., Bertoldi, W., Drake, N.A., 2013. An assessment of the degree to which Landsat TM data can support the assessment of fluvial dynamics, as revealed by changes in vegetation extent and channel position, along a large river. Geomorphology, early view.

Hupp, C.R., Osterkamp, W.R., 1985. Bottomland vegetation distribution along Passage Creek, Virginia, in relation to fluvial landforms. Ecology, 66: 670-681.

Imbert, E. and Lefevre, F., 2003. Dispersal and gene flow of Populus nigra (Salicaceae) along a dynamic river system. Journal of Ecology, 91: 447-456.

Ishikawa, Y., Sakamoto, T., Mizuhara, K., 2003. Effect of density of riparian vegetation on effective tractive force. Journal of Forest Research 8: 235-246

Karrenberg, S., Edwards, P.J., Kollmann, J., 2002. The life history of Salicaceae living in the active zone of floodplains. Freshwater Biology 47: 733-748.

Karrenberg, S., Kollmann, J., Edwards, P.J., Gurnell, A.M., Petts, G.E., 2003. Patterns in woody vegetation along the active zone of a near-natural Alpine river. Basic and Applied Ecology 4: 157-166.

Karrenberg, S., Suter,M. 2003. Phenotypic trade-offs in the sexual reproduction of Salicaceae from flood plains. American Journal of Botany 90(5): 749-754.

Leopold, L.B., Wolman, M.G., 1957. River channel patterns-braided, meandering and straight. U.S. Geological Suruey Professional Paper, 282B 39-85.

Lite, S.J., Stromberg, J.C., 2005. Surface water and ground-water thresholds for maintaining Populus-Salix forests, San Pedro River, Arizona. Biological Conservation 125: 153-167.Liu et al., 2010

Lytle, D.A., Merritt, D.M., 2004. Hydrologic regimes and riparian forests: A structured population model for cottonwood. Ecology 85(9): 2493-2503.

Mahoney, J.M., Rood, S.B., 1998. Streamflow requirements for cottonwood seedling recruitment: an integrative model. . Wetlands 18: 634-645.

Merritt, D.M., Scott, M.L., LeRoy Poff, N., Auble, G.T., Lytle, D.A., 2010. Theory, methods and tools for determining environmental flows for riparian vegetation: riparian vegetation-flow response guilds. Freshwater Biology 55(1): 206-225. 
Merritt, D.M., Wohl, E.E. 2002. Processes governing hydrochory along rivers: hydraulics, hydrology and dispersal phenology. Ecological Applications, 12: 1071-1087.

Moggridge, H.L., Gurnell, A.M., 2009. Controls on the sexual and asexual regeneration of Salicaceae along a highly dynamic, braided river system. Aquatic Sciences 71: 305-317.

Nanson, G.C., Croke, J.C. 1992. A genetic classification of floodplains. Geomorphology 4(6): 459-486.

Osterkamp, W.R., Hupp, C.R. and Stoffel, M., 2012. The interactions between vegetation and erosion: new directions for research at the interface of ecology and geomorphology. Earth Surface Processes and Landforms, 37(1): 23-36.

Perucca, E., Camporeale, C., Ridolfi, L., Gurnell, A.M. in review. Modelling the interactions between river morphodynamics and riparian vegetation.

Petts, G.E.,Gurnell,A.M., Gerrard, A.J., Hannah, D.M., Smith, B.P.G., Edwards, P.J., Kollmann, J., Ward, J.V., Tockner, K. 2000. Longitudinal variations in exposed riverine sediments: a context for the development of vegetated islands along the Fiume Tagliamento, Italy. Aquatic Conservation: Marine and Freshwater Ecosystems, 10: 249-266.

Pezeshki, S. R. and F.D. Shields 2006. Black willow cutting survival in streambank plantings, southeastern United States. Journal of the American Water Resources Association 42(1): 191-200.

Pollen-Bankhead, N., Simon, A., 2010. Hydrologic and hydraulic effects of riparian root networks on streambank stability: Is mechanical root-reinforcement the whole story? Geomorphology 116(3-4): 353-362.

Prosser, I.P., Dietrich, W.E., Stevenson, J., 1995. Flow resistance and sediment transport by concentrated overland flow in a grassland valley. Geomorphology 13: 71-86.

Robertson, K.M., 2006. Distributions of tree species along point bars of 10 rivers in the south-eastern US Coastal Plain. Journal of Biogeography 33: 121-132.

Rouse, J.C., 1973. Monitoring the vernal advancement and retrogradation of natural vegetation. NASA/Goddard Flight Space Center, Greenbelt, MD.

Schumm, S.A., 1977. The Fluvial System. Wiley, New York, 338 pp.

Schumm, S.A., 1985. Patterns of alluvial rivers. Annual reviews of Earth and Planetary Science, 13: 5-27.

Turner, M.G., Gergel, S.E., Dixon, M.D., Miller, J.R., 2004. Distribution and abundance of trees in floodplain forests of the Wisconsin River: Environmental influences at different scales. Journal of Vegetation Science 15: 729-738.

Williams, C.A., Cooper, D.J. 2005, Mechanism of riparian cottonwood decline along regulated rivers, Ecosystems, 8, 382-395.

Zanoni, L., Gurnell, A.M., Drake, N., Surian, N., 2008. Island dynamics in a braided river from an analysis of historical maps and air photographs. River Research and Applications 24: 1141-1159. 
Figure 1 A conceptual model of island development (after Gurnell et al., 2001).

A. Different rates of aggradation and island development (from bare bar surface through pioneer, building and established island development) according to different growth trajectories a, b, and c (for explanation see text).

B. Changes in the number and area of islands under each of the three vegetation growth trajectories $(a, b, c)$ in response to the same sequence of annual floods.

A

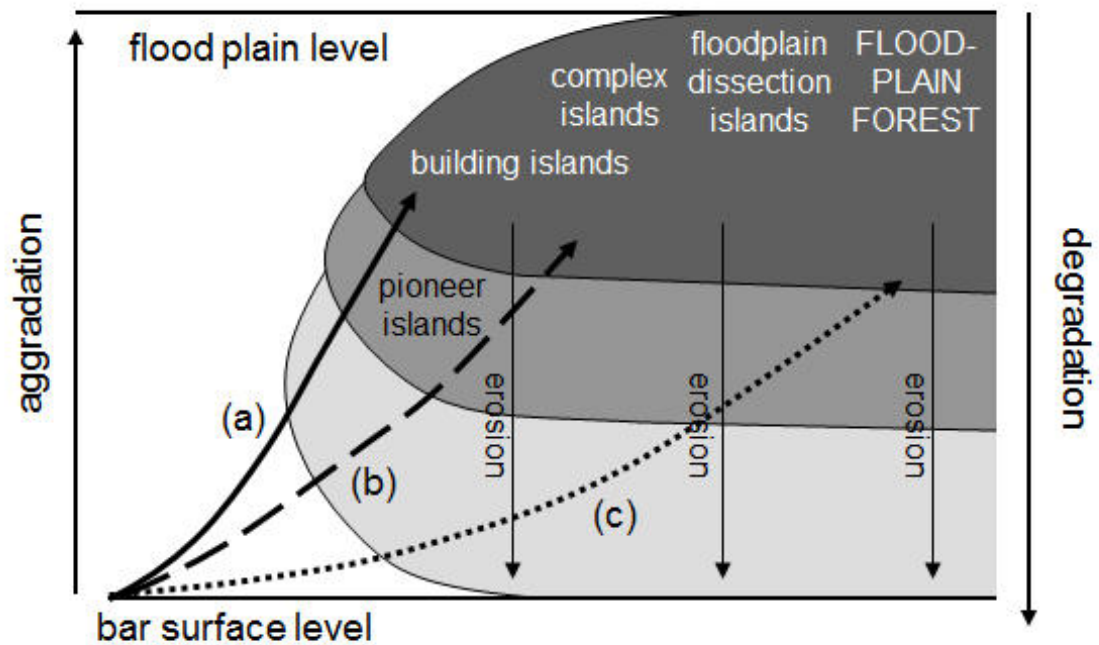

(a) $\longrightarrow$ Time needed for dense vegetation to form

(b) $--\longrightarrow-\longrightarrow \rightarrow$ under different tree growth rates

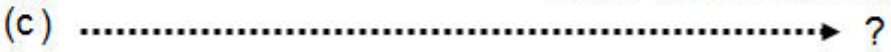

B
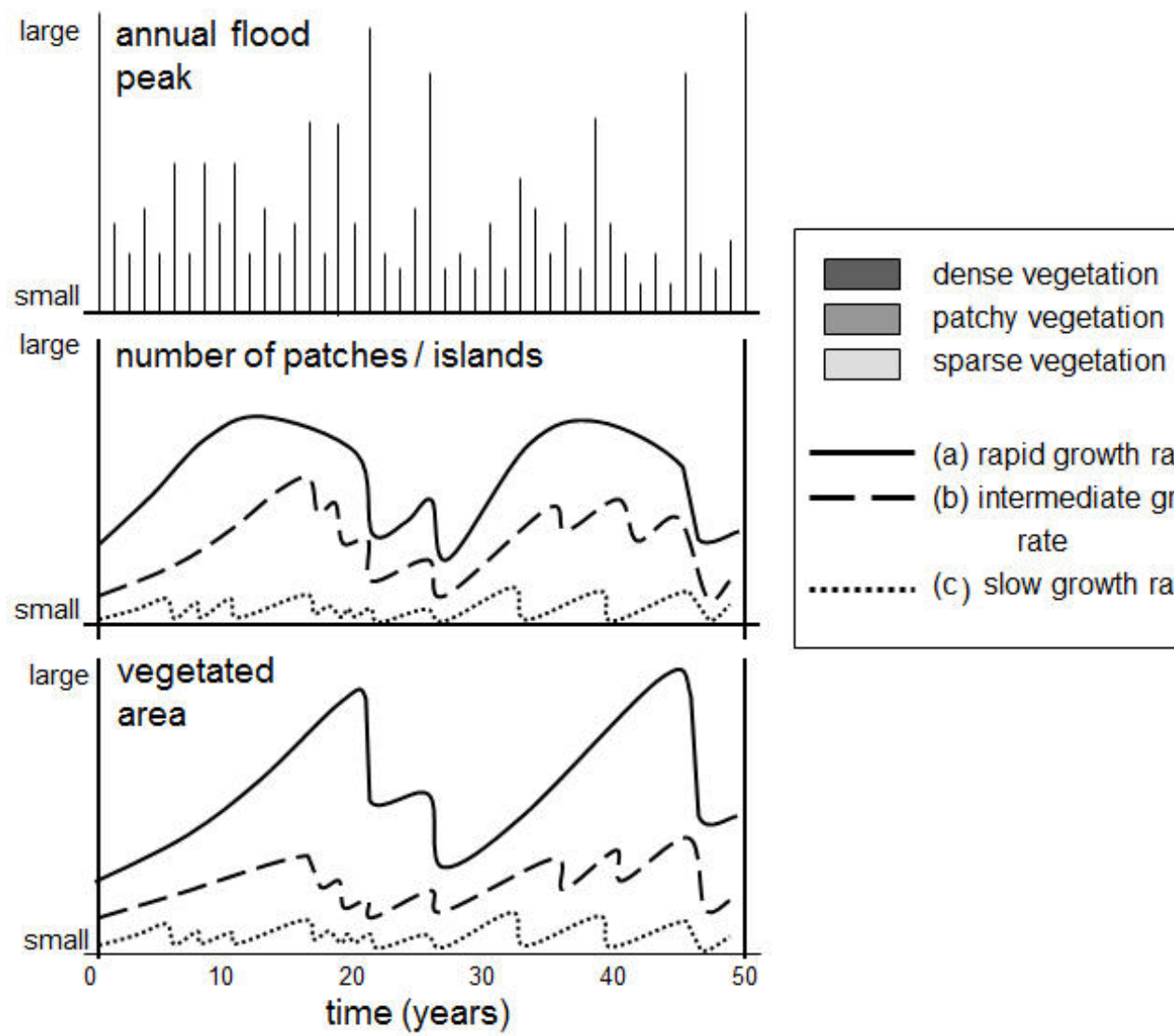

(a) rapid growth rate

(b) intermediate growth rate

(c) slow growth rate 
Figure 2 Downstream variations in river corridor properties along the Tagliamento main stem.

A. elevation, $\mathrm{Q}_{10}$ (method described in Gurnell et al., 2000a), and median particle size of the coarsest patch of main channel edge sediment (method described in Petts et al., 2000; values interpolated to $10 \mathrm{~km}$ intervals using partly unpublished data).

B. Width of the active tract at $0.5 \mathrm{~km}$ downstream intervals, subdivided into width under islands and width under open gravel and water (method described in Gurnell et al., 2000a).
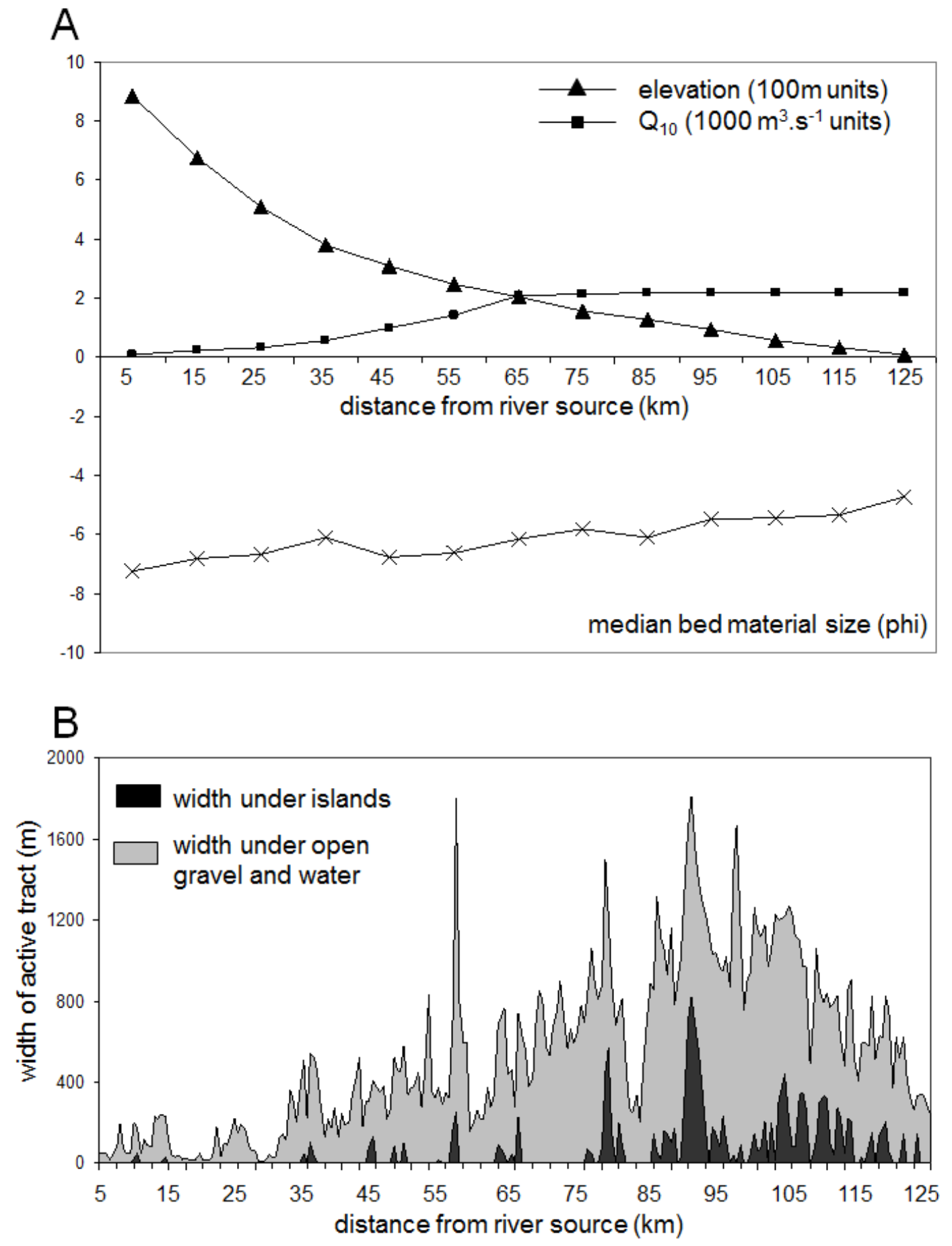
Figure 3 Characteristics of woody vegetation at 10km intervals along the

Tagliamento main stem. At each site, measurements were obtained within $5 \times 50 \mathrm{~m}^{2}$ plots located on vegetated patches within the active tract (data from Karrenberg et al., 2003).

A. average age of oldest tree within each of the 5 plots and number of woody species present

B. basal area of all woody species

C. basal area of A.incana, S. eleagnos and P. nigra
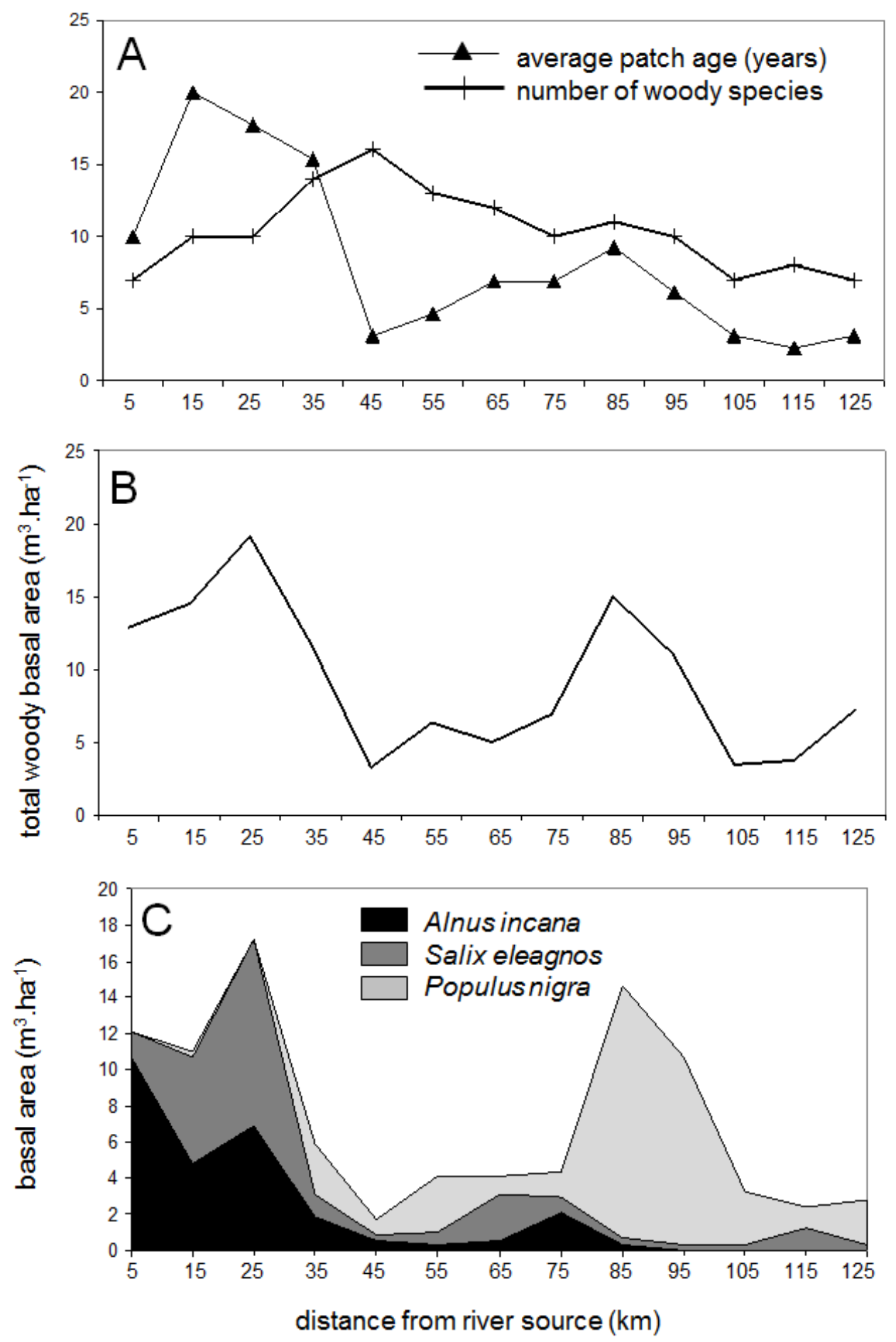
Figure 4 Percentage of the deposited wood biomass exposed on the surface of the active tract that is dead (black) or sprouting / alive (grey) at eight sites along the Tagliamento main stem (data from Gurnell et al., 2000b). Data are presented for the total exposed wood biomass (top) and for different components of the biomass, illustrating a downstream trend in the proportions of the wood according to type and whether dead or sprouting.

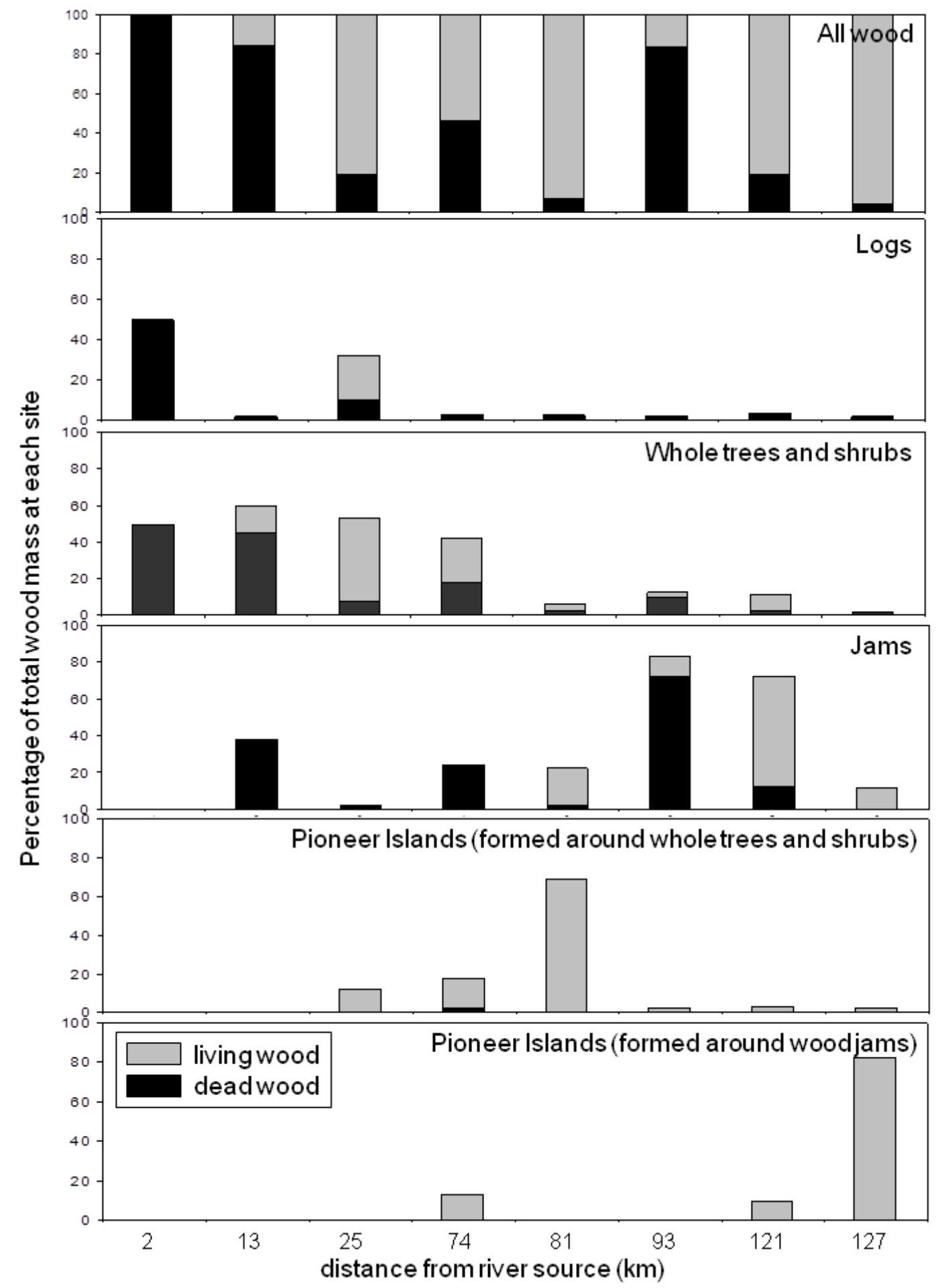


Figure 5 Average daily growth rates of $P$. nigra during the first growing season, based on the length of the main shoot from seedlings and cuttings and the longest of 10 shoots spaced evenly along the trunk of uprooted trees. All sampled individuals were growing on open bar tops on surface sediments ranging from silty-sand to coarse gravel. All measurements were taken at a site $79 \mathrm{~km}$ downstream from the source of the Tagliamento during the 2003 and 2004 growing seasons.

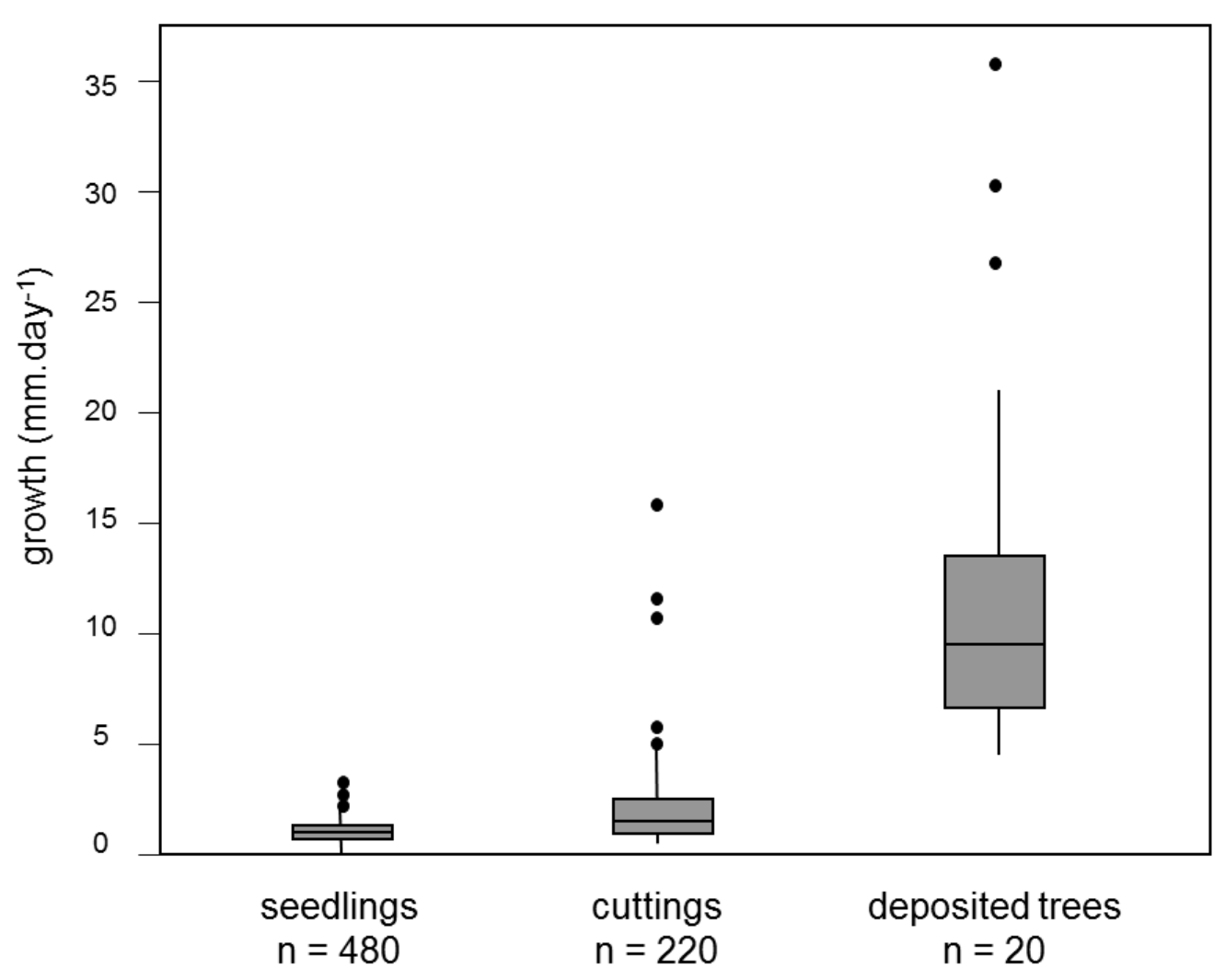


Figure 6 Variations in average annual growth of $P$. nigra across individuals ranging from 2 to 24 years old at a site $79 \mathrm{~km}$ from the source of the Tagliamento (observations collected in 2004 and 2005).
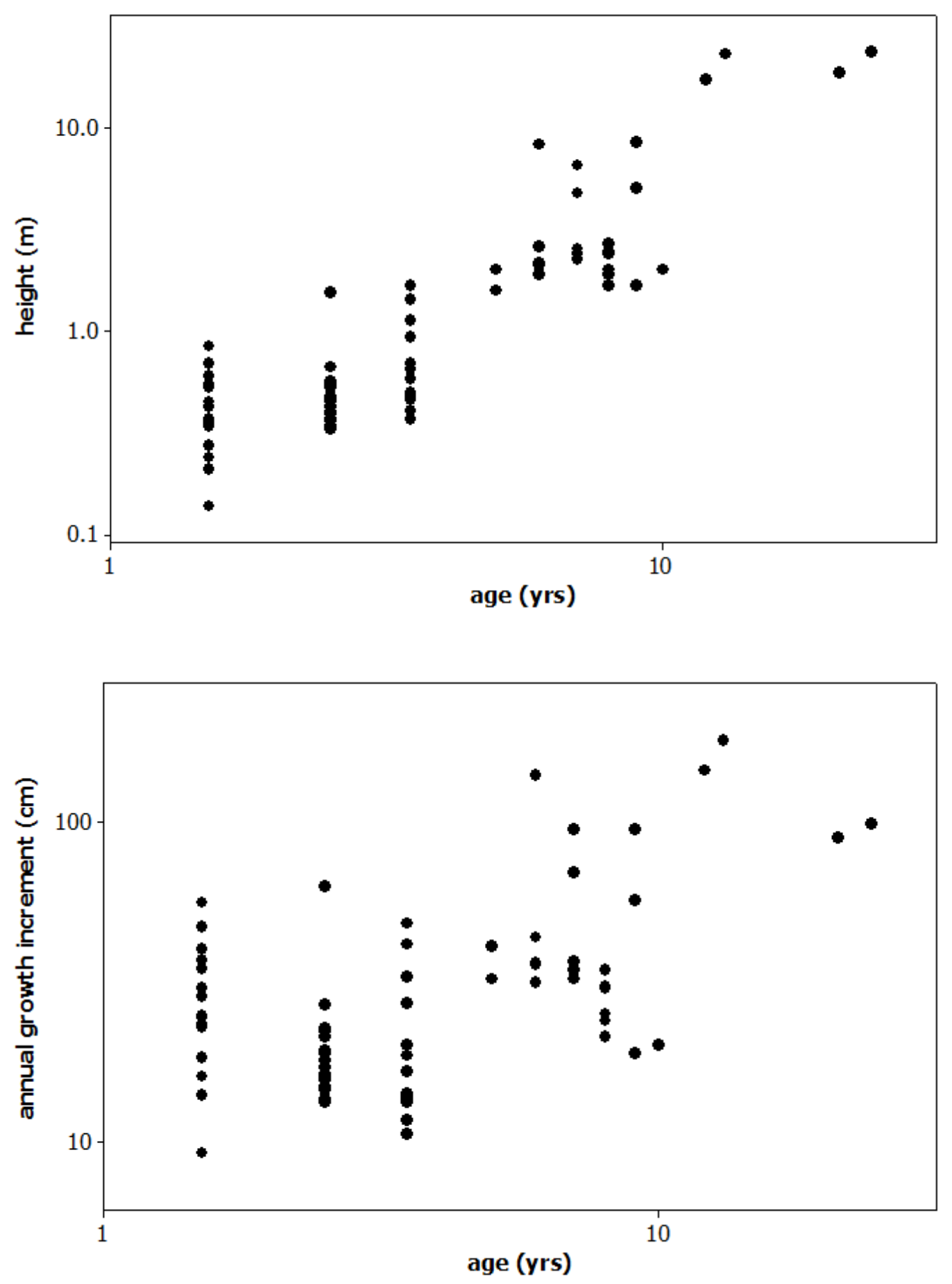
Figure 7 Box and whisker plots of the annual growth increments, measured in 2005 and 2010, of samples of twenty $3 \mathrm{~m}$ tall $P$. nigra located at fifteen sites along the Tagliamento between 71 and $127 \mathrm{~km}$ from the river's source.

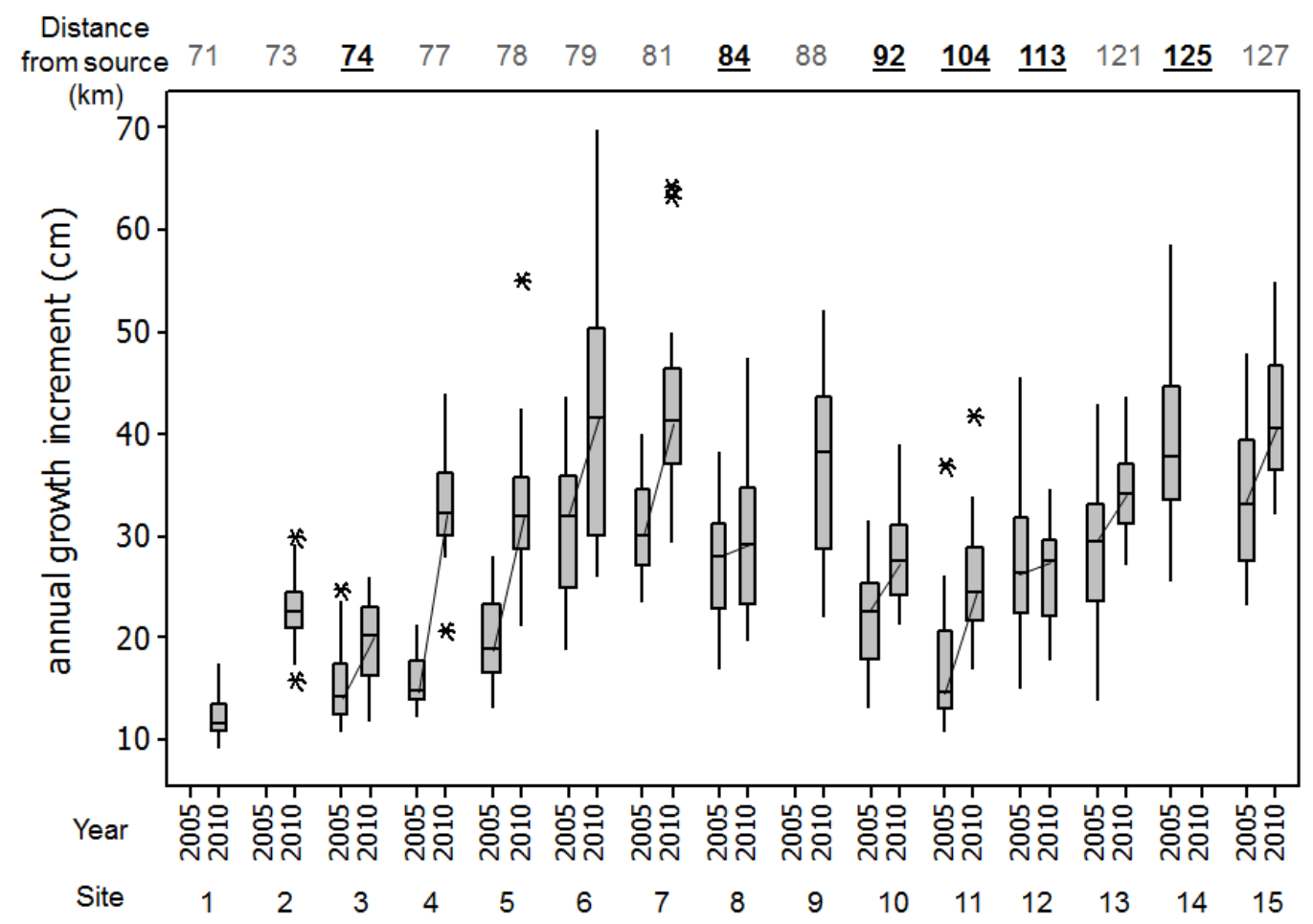


Figure 8

A. Changes in total (sparse and dense) vegetation cover estimated between $68-76 \mathrm{~km}$, $77-83 \mathrm{~km}$, and 83-89 km from six Aster images (August 2005, July 2006,

September 2007, July 2008, August 2008, July 2009).

B. Changes in the number of discrete patches of vegetation (sparse and dense) estimated between river kilometres $68-76 \mathrm{~km}, 77-83 \mathrm{~km}$, and $83-89 \mathrm{~km}$ from the same six Aster images as A.

C. Average hourly water surface levels relative to a local datum at a gauge located at $83 \mathrm{~km}$ from the river's source, 1 January 2005 to 31 December 2009.

(data from Bertoldi et al., 2011a).
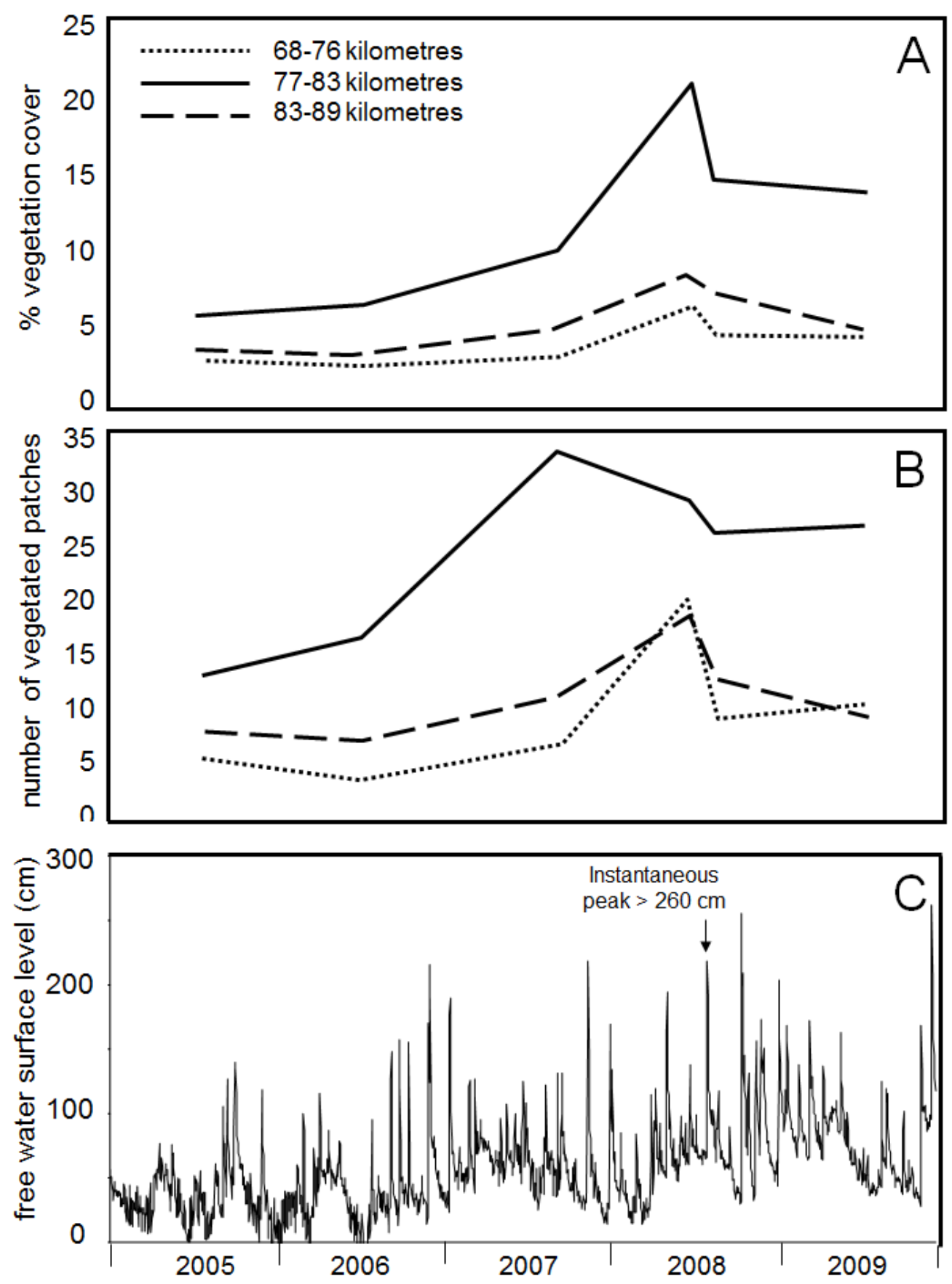
Figure 9 Significance of river stages (monitored at $83 \mathrm{~km}$ ) for inundation of biogeomorphological features within the active tract between 74 and $83 \mathrm{~km}$. The associations are interpreted from repeat photographs of the active tract obtained from 2003 to present. Small, young vegetated features start to appear at around $100 \mathrm{~cm}$ elevation, but large vegetated patches are generally confined to areas above $200 \mathrm{~cm}$ elevation (developed from Bertoldi et al., 2009).

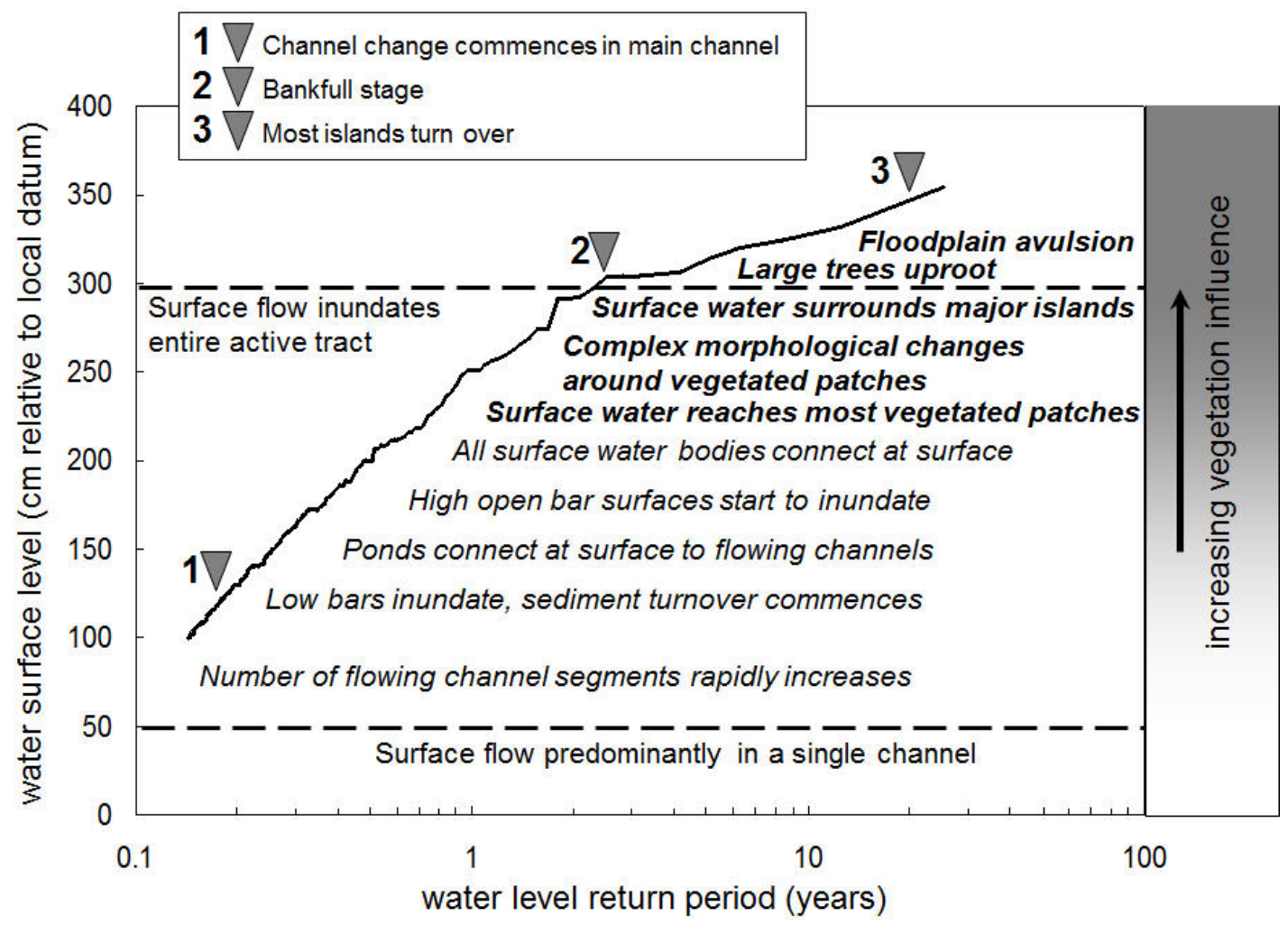


Figure 10

A. Changing vegetation cover during the summer months (June to September) on nineteen occasions between 1984 and 2011. The percentage vegetation cover (black triangles) was estimated for the entire active tract between 77 and $83 \mathrm{~km}$ following classification of the $30 \mathrm{~m}$ pixels of Thematic Mapper scenes into vegetated or unvegetated using a threshold NDVI value of 0.2 (for detailed methodology, see Henshaw et al., 2013)

B. Changing vegetation cover in $1 \mathrm{~km}$ reaches of the Tagliamento active tract between 68 and $89 \mathrm{~km}$ from the river's source in summers 2005, 2008 and 2009 (a reach including a large vegetated, bedrock cored island is excluded). Cover was estimated from Aster data following classification of the $15 \mathrm{~m}$ pixels into heavily vegetated, sparsely vegetated and unvegetated using threshold NDVI values of 0.2 and 0.1 (for detailed methodology, see Bertoldi et al., 2011a).
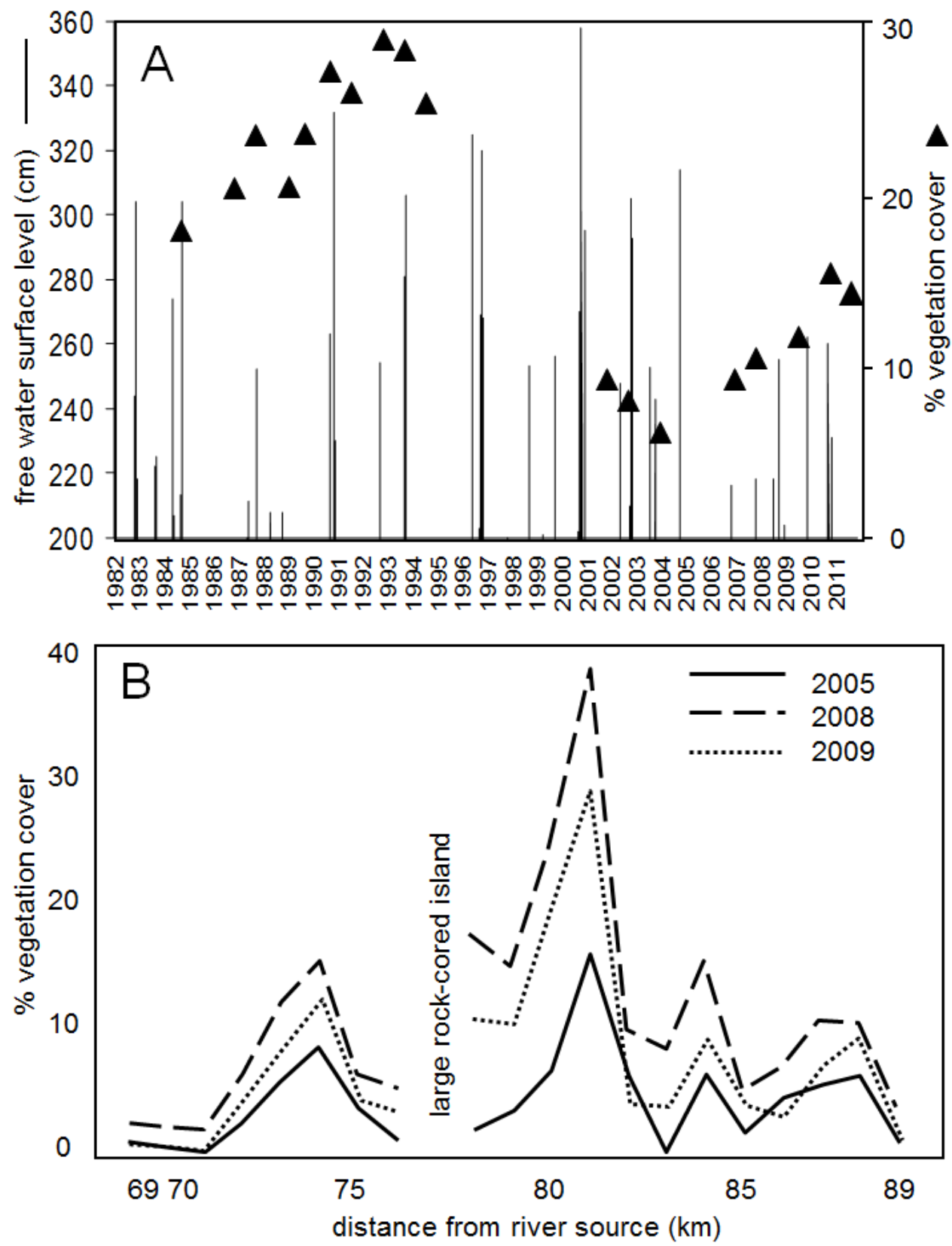
Figure 11 Photographic evidence of changing vegetation cover at a site between 80 and $81 \mathrm{~km}$ from the river's source in the summers of 2001, 2005, 2008 and 2010 (photographs by A.M. Gurnell)

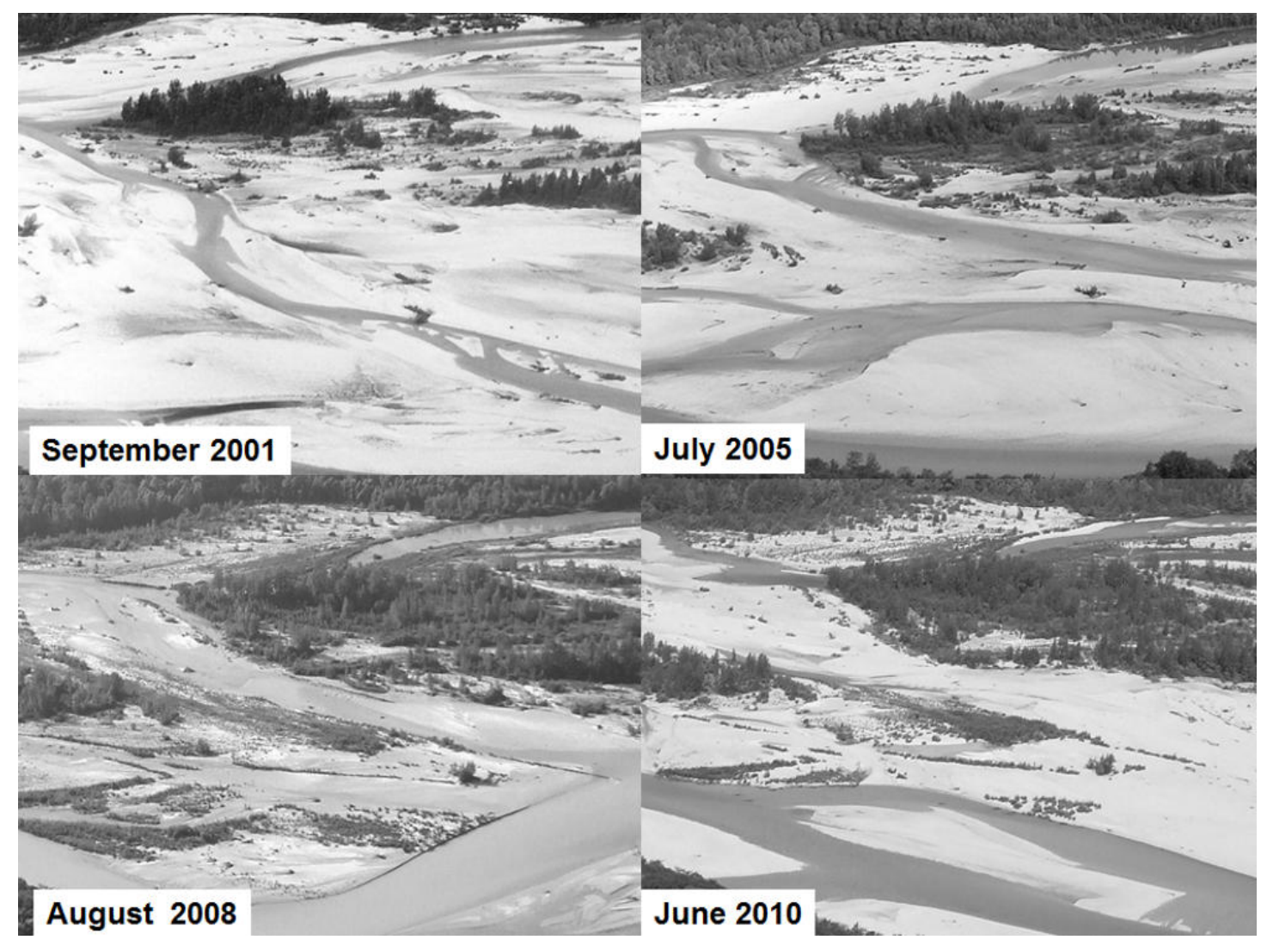


Figure 12

Frequency distributions of river bed elevation within $1 \mathrm{~km}$ segments of the active tract of the Tagliamento River between 68 and $89 \mathrm{~km}$, in the most heavily (A) and least heavily (B) vegetated segments. The bars are subdivided according to the proportion of grid cells at that elevation that are bare gravel (vegetation shorter then $1 \mathrm{~m}$ ), or under vegetation taller than $1,5,10$ and $20 \mathrm{~m}$.

Relationships between average vegetation canopy height in nineteen $1 \mathrm{~km}$ segments of the Tagliamento River between 68 and $89 \mathrm{~km}$ and the skewness ( C) and kurtosis (D) of the frequency distribution of river bed elevation.

(data from Bertoldi et al., 2011b)
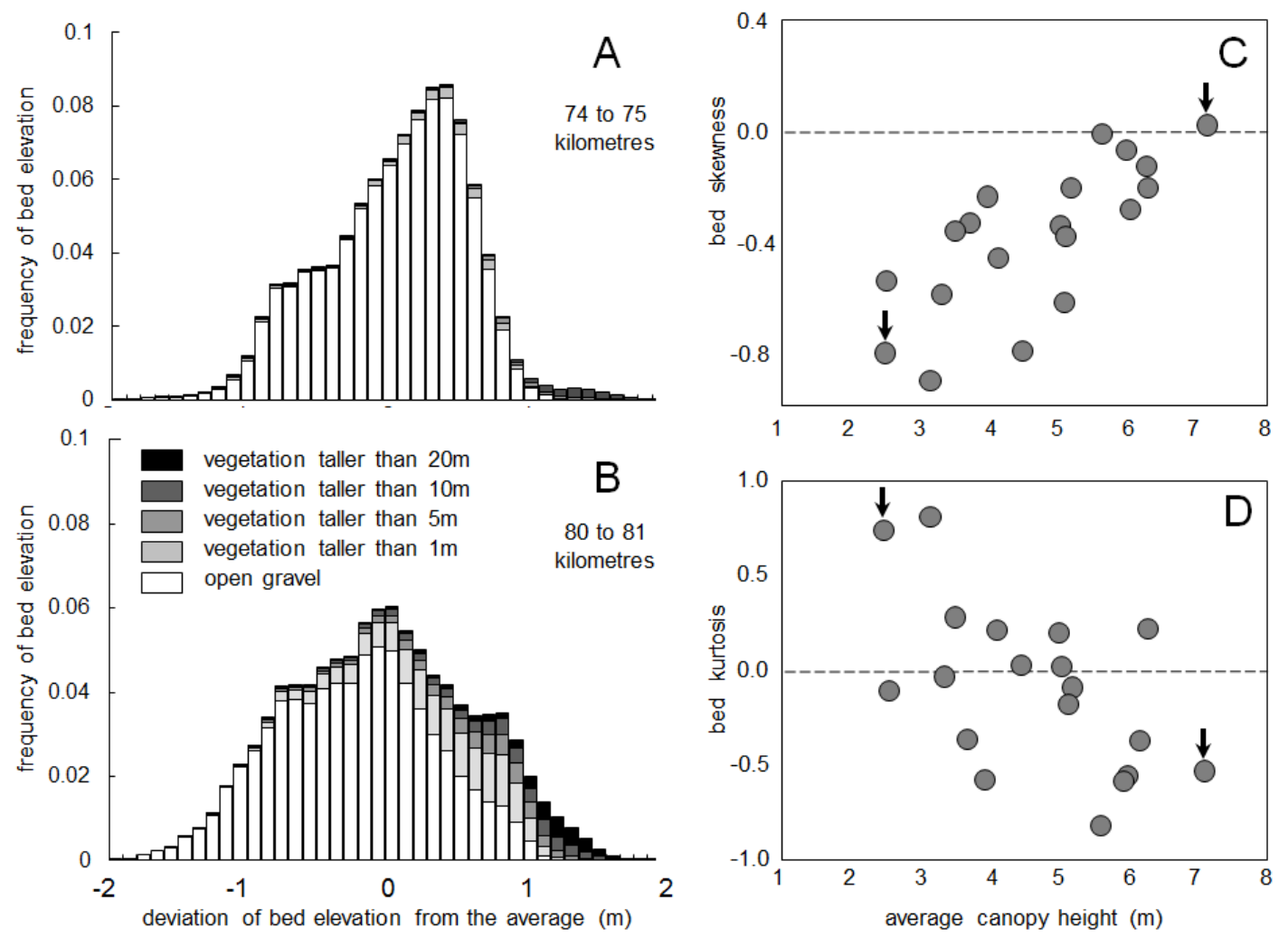